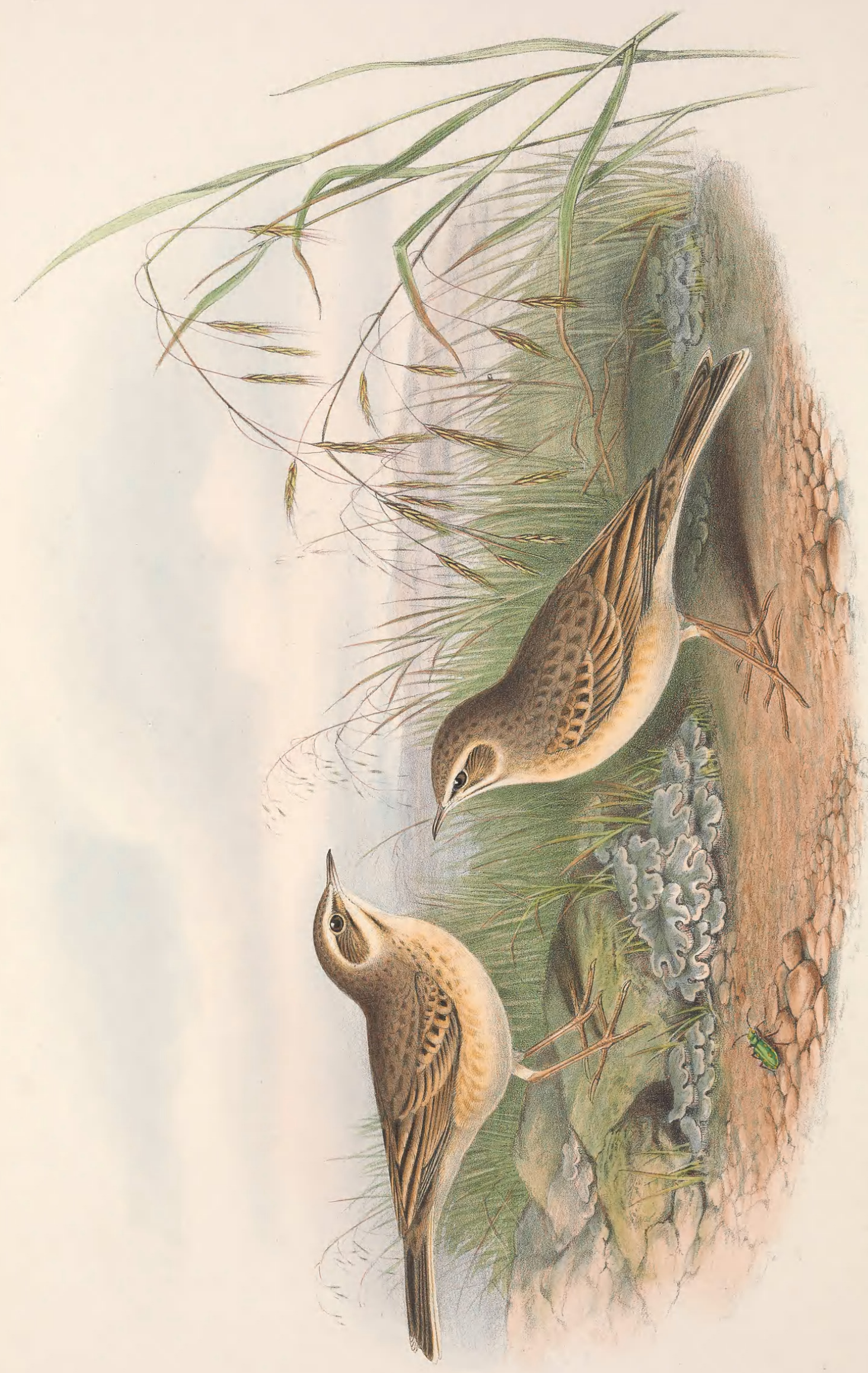

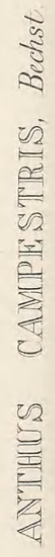




\title{
ANTHUS CAMPESTRIS.
}

\section{Tawny Pipit.}

\author{
Alauda campestris, Briss. Orn., tom. iii. p. 349. \\ Anthus campestris, Bechst. Naturg. Deutschl., tom. iii. p. 722. \\ rufescens, Temin. Man. d'Orn., tom. i. p. 267. \\ Alauda mosellana, Gmel. edit. Linn. Syst. Nat., tom. i. p. 794. \\ - grandior, Pall. Zoog. Ross.-Asiat., tom. i. p. 525. \\ Agrodroma rufescens, Swains. Class. of Birds, vol. ii. p. 293. \\ campestris, Jerd. Birds of India, vol. ii. p. 234. \\ Anthus paludosa, Bonn. Ency. Méth. Orn., part 1. p. 313.
}

THE first instances of the occurrence of this bird in Britain were recorded in the 'Ibis' for 1863, by G. Dawson Rowley, Esq., of Brighton, a gentleman much attached to the ornithology of this country; and as from his well-known acumen and research with regard to the oology of our islands his opinions are regarded with attention, I cannot do better than give his account of them nearly in his own words :-

"The fact that the Tawny Pipit is common in France would lead us to suppose it might be found more or less frequently on our south coasts. I think I can prove that in two instances it has been shot near Brighton, and I have little doubt that more examples would have been noticed had the attention of Ornithologists been directed to the species. Late on the evening of September 24, 1862, a person named Wing brought a Pipit in the flesh to Mr. George Swaysland, of Queen's Road, Brighton, with directions to stuff it for him. Swaysland saw at once that it was a curious bird, induced Wing to part with it, took a note of where it was procured, and sent for me. The memorandum stated that Wing had shot the bird on the cliff about a mile and a half from Rottingdean near Brighton. Under the impression that it was Anthus Richardi, I compared it with the descriptions of that species in the works of Yarrell and Morris; but the hind claw proving much too short I began to suspect we had a new bird before us. Ultimately I sent it to Mr. Gould, who replied, 'the bird is the Tawny Pipit (Anthus compestris), apparently a fine old male, in summer plumage. The spotted markings on the chest are unusual, but I have no doubt I am right as to its name; others ought to be found on our southern coasts, as the bird is common in the central parts of France and Spain.'

"I and Swaysland had previously thought that it was a young bird of the year, and still incline to that opinion, though hesitating to differ from so great an authority. We were induced to think so by the fine hair-like feathers about the vent, and the light edging of the feathers of the back, a character which is to be found in all our Larks and Pipits during their first plumage. It subsequently came to our remembrance that another specimen, which had been sold to Henry Collins, Esq., of Aldsworth near Emsworth, as an Anthus Richardi, was precisely like the one under examination. Upon this I wrote to Mr. Collins, a gentleman whose collection is rich in British-killed birds; and he, in the most liberal manner, directly placed it at my disposal. I knew there could not be the slightest doubt that the latter was a bonâ fide British-killed bird, as it had been shot by Harding, a domestic servant in Brighton, and a highly respectable man, with whom I am well acquainted and cân quite depend upon. I was therefore much pleased to find it exactly similar to the other, particularly in the short hind claw, which is long in A. Richardi, and to observe that Mr. Collins's example is even finer than Swaysland's. On inquiry, Harding informed me that it was shot by him on the 17th of August 1858, about seven o'clock in the morning, close to a shallow pool near Shoreham Harbour. Upon my asking what called his attention to this bird more than others, he having mentioned that there were several Rock-Pipits about at the time and Meadow-Pipits in abundance, he said its note struck him as different to the Titlark's-'It came piping down from above,' and readily allowed him to approach. Mr. Collins's bird, which I believe is also a male, is evidently older than Swaysland's. It seems probable, when we consider the time of year at which it was killed, that it had bred somewhere in this country, perhaps not far off, and was about to depart. The Rottingdean bird likewise had doubtless migration in view. Mr. Tristram says this bird is the Pipit of the Sahara, and Mr. Wheelwright states that it occurs in Sweden. Ranging so widely, it is strange no instances of its occurrence here have been previously recorded."

In $1865 \mathrm{Mr}$. Rowley reported in the 'Ibis' that a third example had been caught near Brighton, and brought alive to Mr. Swaysland on the 30th of September 1864.

That other individuals have from time to time been killed in England and mistaken for Richard's Pipits, I think is more than probable; and now that attention has been directed to the subject, others will doubtless be detected; for it is hardly to be supposed that a bird so common upon the continent of Europe during 
the months of summer should not occasionally stray out of its course and risit the British Islands. This country, however, seems but ill adapted for a lengthened sojourn, its habits being peculiar, and the situations it affects not being numerous in our humid climate; for it is in open sterile districts, and such hot and parched localities as occur in many parts of France, Spain, and Italy, that the bird finds a congenial home, just as the Meadow-Pipit does in the soft boggy parts of our moorlands. How different are the habits of the two species, and how instructive is a knowledge of them! This difference at once accounts for the very opposite styles of their colouring, one being dressed in dust-coloured feathers of a hue very similar to that of the sand over which it runs, the other in an olive-green costume, assimilating in tint to the grassy herbage of the moorlands, the swamps, and the hillsides it frequents.

The Tawny Pipit, which is more commonly known by the name of Anthus rufescens than by that of A. campestris, first assigned to it, is strictly a summer visitant to most parts of the European continent, particularly France, Germany, Italy, and Spain. It proceeds as far north as Southern Sweden, is much more numerous in North Africa, and is equally abundant in Palestine, Persia, Scinde, and the peninsula of India, where Mr. Jerdon states it is found in all suitable places, and adds, "I have noticed that it is most abundant in the Deccan, at Mhow in Central India, and on the Eastern Ghauts; it is rare in the Carnatic. Blyth has it from Midnapore and the north-western provinces. It frequents barren, open, stony land, and is never found in rich pastures or meadows."

Bailly states that in Savoy it is a bird of passage, and is never very common; " it arrives in April and returns again during the first fortnight of October. In spring it generally appears singly, in couples, or in threes, and in autumn in small flocks of from three to five. A few remain and breed among small stony hillocks thinly clothed with shrubs and heath, the nest being constructed early in May, at the foot of a small shrub, a tuft of grass, or other plants ; it is composed of small pieces of moss, dried grasses, and roots, lined with wool, horsehair, and vegetable fibres; the eggs, are five or six in number, white, or bluish white, sprinkled with small spots, streaks, and dashes of brown, violet, and brownish red. During the period of incubation the male diligently feeds the female, and continues to solace her with his song, consisting of one or two notes repeated fifteen or twenty times in succession while obliquely ascending to a moderate height and dropping again almost vertically to the ground; these notes are less frequently heard after the young are hatched, and by the middle of July cease entirely. About the end of August or the beginning of September the Tawny Pipit resorts to the plains and the ploughed lands, retiring during the middle or hotter part of the day to the shelter of the hills. Its food consists of maggots, small worms, millepedes, small spiders, and grasshoppers, flies and other insects caught while flying, and small snails seized from the stalks of grasses. It evinces but little fear of man, and on being disturbed merely runs with great swiftness to a short distance, and then stops as if to ascertain the cause of its fear. When a small number travel in company, they frequently call to each other; by imitating this call our bird-catchers easily entice them into their traps."

M. Dubois, in his work on the Birds of Belgium, informs us that the Tawny Pipit evinces a "preference for extensive dry plains, where but few trees or plants occur, and shuns high grass and bushes. It is almost always on the ground, sometimes perched upon a hillock or stone, or a bush, but is rarely found on trees. Is very lively, but shy or coy in its movements. The singular song of the male is composed of a series of short, uniform, and melancholy notes which it utters while flying. The nest is placed in slight hollows of the ground, sheltered by a bush. The young quit the nest before they can fly; for they can always run sufficiently well to hide themselves in the grass, corn, or brushwood."

Degland states that it sometimes constructs its nest in the crerices of rocks, that it runs both quickly and gracefully, that it rarely perches on trees, and that its cry is very like that of the Short-toed Lark.

The Rev. Mr. Tristram informed Dr. Bree that the egg of this bird is very variable, though not so much so as that of Anthus arboreus. Some of his specimens approach those of the Pied Wagtail ; in others the russet spots are as large, thick, and bright as in Sylvia galactodes, which egg this variety greatly resembles.

During the breeding-season the feathers of the upper surface of the male are light brown in the centre, so largely margined with greyish buff that the darker tint is but little perceptible, and the whole presents a mealy appearance; wings dark brown, all the feathers except the primaries broadly margined with bright buff, with a reddish tinge on those bordering the coverts and secondaries; primaries brown, narrowly edged with greyish buff; two centre tail-feathers dark brown, bordered with greyish buff; two outer tail-feathers buffy white, with a broad stripe of dark brown down the margin of the inner web, and a narrow interrupted line of the same hue on the outer web towards the tip; the remaining tail-feathers dark brown; over the eye a streak of buffy white; ear-coverts dark brown; a small moustache-like streak of brown on each side beneath the eye; all the under surface very pale buff, washed with a deeper tint across the breast and down the flanks; a few faint streaks of brown on the sides of the neck and breast; irides brown; upper mandible blackish brown, lower mandible yellowish; tarsi and feet flesh-colour.

The figures are of the natural size. The beetle is the Cicindela campestris. 


\section{$2 \mathrm{BHL}$ Biodiversity Heritage Library}

Gould, John. 1873. "Tawny Pipit, Anthus campestris [PI. 9]." The birds of Great Britain 3, -. https://doi.org/10.5962/p.323900.

View This Item Online: https://www.biodiversitylibrary.org/item/221726

DOI: https://doi.org/10.5962/p.323900

Permalink: https://www.biodiversitylibrary.org/partpdf/323900

\section{Holding Institution}

Smithsonian Libraries

\section{Sponsored by}

Biodiversity Heritage Library

\section{Copyright \& Reuse}

Copyright Status: Public domain. The BHL considers that this work is no longer under copyright protection.

This document was created from content at the Biodiversity Heritage Library, the world's largest open access digital library for biodiversity literature and archives. Visit BHL at https://www.biodiversitylibrary.org. 